\title{
Epoprostenol Sodium
}

National Cancer Institute

\section{Source}

National Cancer Institute. Epoprostenol Sodium. NCI Thesaurus. Code C47514.

The sodium salt form of epoprostenol, a synthetic prostacyclin, a member of the family of prostaglandins, with vasodilatory and anticoagulant activity. Epoprostenol sodium directly simulates prostaglandin receptors in arterial vascular smooth muscle, thereby causing vasodilatation. This agent also inhibits platelet aggregation by antagonizing platelet glycoprotein (GP) IIb/llla receptors, thereby preventing thrombus formation. 